\title{
Employee Theft among College Students in the Workforce
}

\author{
Thanasak Ruankaew ${ }^{1}$ \\ ${ }^{1}$ School of Business, Colorado State University-Global Campus, Colorado, USA \\ Correspondence: Dr. Thanasak Ruankaew, School of Business, Colorado State University-Global Campus, USA.
}

Received: January 31, 2019

Accepted: February 28, 2019

Online Published: March 13, 2019

doi:10.5539/ibr.v12n4p40

URL: https://doi.org/10.5539/ibr.v12n4p40

\begin{abstract}
Employee theft costs organizations billions of dollars annually. Despite the severity of employee theft, previous research has not focused on the specific demographics of employees who commit this crime. The number of college students in the workforce has increased over the years; thus, the purpose of this study was to investigate the serious problem of employee theft, particularly in relation to the college student population. A survey was used to collect data from college students to indicate employee theft activities among them. Employee theft activities were categorized as follows: time theft, property theft, embezzlement, pilferage, and data and trade secret theft. Survey responses from 92 students indicated that the majority committed time theft, followed by property theft, pilferage, data and trade secret theft, and embezzlement, respectively. This study adds valuable information for businesses and practitioners to understand the severity of employee theft among the increasing number of college students in the workforce.
\end{abstract}

Keywords: employee theft, college student employees, college student theft

\section{Introduction}

Employee thefts are crimes committed by employees for the purpose of personal gain. The issue of employee theft is considered an important one that deserves serious attention from organizations. According to Omar et al. (2011) and Weber, Kurke, and Pentico (2003), employee theft affects approximately 95\% of all businesses and costs them billions of dollars each year. While much research suggests that the magnitude of employee theft in organizations is on the rise, the author believes additional research focusing on specific demographics of employee theft should be conducted. The author's proposal is supported by Peterson and Zikmund (2004), who indicated that research on employee theft and other unethical behaviors has failed to investigate the unique demographics of employees in the workplace.

The number of college students in the workforce has increased steadily in the past four decades (Riggert et al., 2006), both in terms of the number of students employed and the number of hours they work (Bozick, 2007; Oliver, 2009). Student workers are a significant proportion of the labor market. It is not surprising that the number of students who are employed and the number of hours they work have increased over the years. More Americans understand the value of education and view higher learning as an American ideal (Riggert et al., 2006). While striving for this opportunity, however, most students also must work to fund their education, for which expenses are high and continually rising (Kulm \& Cramer, 2006; Riggert et al., 2006). Approximately 80\% of all college students are employed, with more than 50\% employed for an average of 29 hours per week during the school year (DeSimone, 2008; Riggert et al., 2006). With both college student employment and employee theft increasing, research on employee theft has been challenged based on the different forms, degrees, and causes of theft (Niehoff \& Paul, 2000). Therefore, research that focuses specifically on employee theft within this demographic and on different types of employee theft (time theft, theft of property, embezzlement, pilferage, and data and trade secret theft) will benefit businesses and practitioners by providing important insights into the gravity of employee theft among college students.

\section{Objectives}

Despite the magnitude of employee theft and the increasing number of college students in the workforce, studies on employee theft among these students are limited. With an increase in college student employment, previous research has indicated that college student employees' propensity to engage in theft is also increasing (Graves, 2008). The purpose of this study, therefore, was to investigate the severity of employee theft among the college student population and to determine the various types of employee theft among these students. The types of 
employee theft covered by this study are time theft, property theft, embezzlement, pilferage, and data and trade secret theft. Each form of theft was measured based on the rate of the following behaviors: misusing time during work hours (time theft), misusing an employer's property (property theft), dishonestly appropriating or hiding funds/money (embezzlement), obtaining small items for personal use (pilferage), and taking/changing confidential information without authorization (data and trade secret theft). Identifying the seriousness of employee theft among college students will help organizational leaders and practitioners manage the risks proactively and efficiently.

\section{Literature Review}

The purpose of this study was to investigate the severity of employee theft among college students. To achieve this research objective, a literature review is crucial. The first section in the literature review focuses on the significance and urgency of employee theft. The last section of this literature review features information on how businesses react to employee theft.

\subsection{Significance of Employee Theft}

Employee thefts are crimes committed in various types of organizations. Research indicated that both private and public organizations have experienced being victims of this behavior (Kelly \& Hartley, 2010). Business organizations continue to face the issue of employee theft, and combating this issue is a challenge. Previous data revealed that the rate of employee theft has been rising steadily, and the problem has grown in severity (Alstete, 2006; Daigle, Morris, \& Hayes, 2009). Research has also indicated that, of all the new businesses that fail within the first year, as many as $50 \%$ fail as a result of employee theft (Krippel et al., 2008).

Employee theft is a threat that organizations cannot ignore and must attempt to minimize. The top-three threats for American businesses are (a) employee theft, (b) workplace violence, and (c) fraud and white-collar crime, with two of the three threats related to embezzlement (Johnson \& Indvik, 2002). Employee theft is recognized as a problem among many types of organizations and industries. Further, many businesses such as retailers, bankers, manufacturers, builders, grocers, small businesses, restaurateurs, hospitals, pharmacies, nursing homes, service providers, law firms, and government agencies experience employee theft; it is even recognized as a problem by librarians (Sauser, 2007). Among employee theft cases, privately owned businesses comprise the largest group of all organizational victims, with the median loss in the private business sector higher than government and nonprofit agencies (Holtfreter, 2004). Economically, the cost of employee theft to businesses can be more than the value of what was taken. The extra costs as a result of employee theft also include recruiting, interviewing, screening, and the cost of rehiring (Appelbaum, Cottin, Paré, \& Shapiro, 2006).

Everyone in the organization can be a potential thief, and most employees have admitted to having taken something from work. Indeed, one survey discovered that $75 \%$ of employees admitted taking property from their employers at least once (Appelbaum et al., 2006; Everton, Jolton, \& Mastrangelo, 2007; Moorthy et al., 2010). Another survey indicated that $86 \%$ of employees engaged in personal email at work, and $30 \%$ to $40 \%$ of employees claimed they had used the Internet at work for personal purposes (Latto, 2007). It is estimated that American businesses lose approximately $\$ 85$ billion a year as a result of Internet misuse in the workplace (Latto, 2007). Employee theft and abuse are not only limited to lower-level employees within organizations. In an interview with 200 chief executive officers (CEOs), Zeune (2000) found that all the CEOs admitted they have executives who steal, and $67 \%$ of the executives said that fraud in the workplace was worsening. Surprisingly, a large number of employees believe that taking goods from their companies for personal use is not considered theft (Appelbaum et al., 2006). Despite the fact that a large percentage of employees commit unethical behavior regardless of their position in their organizations, researchers have called for more research to precisely identify patterns among specific employee demographics (Van Fleet \& Van Fleet, 2006).

Research on the impact of employee theft has been conducted in various businesses and industries. In a study within a retail industry, the literature shows that the employee theft situation is intensifying and is a major cause of retail loss (Alstete, 2006; Bamfield, 2006). Despite the perception of shoplifting being high among retailers compared with employee theft, the cost of shoplifting is not as high as the cost of employee theft. It has been estimated that, for every $\$ 1$ stolen by shoplifters, $\$ 11$ are estimated to be stolen by employees (Krippel et al., 2008). Thus, the retail industry lost approximately $\$ 41.6$ billion in 2006 or $1.61 \%$ of sales to employee theft, which was nearly unchanged from $1.60 \%$ in 2005 (Grannis, 2007). In 1974, a survey of 100 retail employees revealed that about half had taken items from their employers (Sauser, 2007). Another research study conducted by the Food Marketing Institute in 1987 found that, among all thefts in supermarkets, 52.9\% were attributed to employees (Sauser, 2007). The term "shrinkage" is commonly used in the retail sector to identify the loss of merchandise as a result of employee and customer theft (Alstete, 2006). Among shrinkage cases in the retail 
sector in the United States, employee theft is the largest cause at $47 \%$ or $\$ 15.8$ billion, whereas customer theft is estimated to contribute to $32 \%$ of shrinkage (Alstete, 2006). This concludes that employee theft is a major contributor to inventory loss in the retail industry.

Another research group examined the impact of employee theft in the hospitality industry. The results showed that restaurant industry losses account for approximately $7 \%$ to $10 \%$ of gross sales annually, and $35 \%$ of restaurant failures were due to employee theft (Krippel et al., 2008). In addition, 50\% of businesses in the hospitality industry reported employee theft incidents, with the cost of thefts more than doubling from 2000 to 2005 (Krippel et al., 2008). In the insurance industry, it is estimated that one-third of businesses fail as a result of employee theft (Mohsin, 2006). Notably, many employers appear to underestimate the level of employee theft in their organizations. Many businesses perceive employee theft as unpreventable and view it as part of doing business (Appelbaum et al., 2006; Bailey, 2006). The methods used to commit theft take various forms and techniques. The methods perpetrators normally use include stealing merchandise and cash, retaining a receipt to show that stolen items were actually purchased, overcharging and undercharging, voiding sales or not recording sales after the customers pay cash for the items, coupon stuffing, and issuing credit for nonexistent returned items (Mishra \& Prasad, 2006). The U.S. Chamber of Commerce data indicated that up to $75 \%$ of employees admitted to stealing at least once, and most of them said they would continue to do so repeatedly (Aker, 2009; Appelbaum et al., 2006). Although many organizations experience employee theft, a high percentage of theft cases is never discovered. Unfortunately, previous research estimated that $75 \%$ of employee theft is never detected, which suggests that, although business owners do not see or have information on this behavior, it may still be occurring (Jackson, Holland, Albrecht, \& Woolstenhulme, 2010).

Employee theft is often thought to be associated with low-value physical items; however, thefts can encompass much larger items such as computers, office equipment, or high-value test equipment (Moorthy et al., 2010). Misappropriating assets or asset theft typically involves employees who find a way to divert some of their employer's cash flow into their own pockets (Buckhoff, Higgins, \& Sinclair, 2010). Of all fraud cases, $85.5 \%$ to $89 \%$ are related to misappropriating assets, including stealing cash and other inventory (Daigle et al., 2007; Krippel et al., 2008). Peltier-Rivest (2009) estimated that asset misappropriation may contribute to as high as $90 \%$ of all fraud cases and are the most frequent fraud schemes. Although other available assets are available in businesses, employees tend to steal items that are useful such as clothing, groceries, electronics, and jewelry (Wells, 2003). Lord (2010) investigated median losses from fraud and found that, although the median losses of asset misappropriation were not as high as financial statement fraud, asset misappropriations occurred most frequently. The same study also showed that the median loss from asset misappropriation schemes was $\$ 150,000$ compared with $\$ 2$ million for financial statement fraud. Lord concluded that, despite this difference, the median loss of \$150,000 from misappropriating assets is considered a large amount of money for small businesses.

Research on occupational fraud and theft in different organizational settings conducted by Peltier-Rivest (2009) showed that organizations that employed fewer than 100 employees experienced a higher percentage of losses in terms of sales size. In the same study, analysis also indicated that, whether measuring the size of the organization by the number of employees or by annual gross sales, fraud losses would likely be higher in smaller organizations. However, this research result appeared to be contradicted by other research. McClurg and Butler's (2006) study stated that, as organization size increases, employee theft can increase due to a decrease in the degree of supervision. This explanation is related to the issue of proximal situations, which posits that employees tend to steal more often in impersonal situations or when the victim is less known by the perpetrator. The length of time for businesses to notice that fraud and theft occurs is varied; in some cases, it may be too late. The average length of time fraud and theft occurs before discovery is about 18 to 24 months (Lord, 2010; Nilsen, 2010). With this amount of time, businesses' ability to recognize the warning signs will help them to prevent and eliminate further losses. The most frequently noticed signals were inventory losses; changes in employees' lifestyles, spending habits, or behavior; and reductions in employee morale and attendance (Fletcher \& Miles, 1997). Although it is important for businesses to look for red flags, businesses need to understand that such signals are merely indicators and do not indicate that fraud or theft are occurring (Peterson \& Zikmund, 2004). After theft and unethical behaviors are discovered, businesses need to look beyond the monetary losses and consider possible damage done to the entity's books, which requires money and time from other employees to correct finances (Tootle, 2008). In the worst cases, businesses may never recover at all (Tootle, 2008).

\subsection{Business Response to Employee Theft}

Despite businesses being aware of the severity and significance of employee theft, an attempt to minimize this behavior, however, is challenging due to the businesses' own attitude. Many business owners consider employee theft unpreventable and believe it is part of the cost of doing business, yet research has revealed this is the wrong 
attitude for businesses (Appelbaum et al., 2006). Some business owners perceive internal and external theft differently; they perceive internal theft as a loss, not a crime (Appelbaum et al., 2006). Consequently, few employees get caught stealing, most cases of employee theft go unobserved, and businesses rarely publicize it when employees are caught (Mohsin, 2006).

Discussing the actual theft rate in the organizations may not be realistic and can be difficult due to the nature of the data. There are several reasons that explain the challenge investigators have to consider when gathering employee theft data. Because not all employee theft incidents are detected and not all are reported, statistics related to fraud and theft are only estimates (Peterson \& Zikmund, 2004). In addition, reports and data related to the employee theft rate are gathered from employee and employer surveys, which may cause the theft rate to be inaccurate and underreported (Appelbaum et al., 2006; Bailey, 2006). For example, a study of restaurant workers from 2001 indicated that an average restaurant worker steals approximately \$204 each year, an increase of \$98 from three years earlier (Kidwell \& Kochanowski, 2005). Experts believe, however, that the results in this study might be low because the National Service Security Council gathered this data from self-reports (Kidwell \& Kochanowski, 2005). Oliphant and Oliphant (2001) indicated that several studies have attempted to identify an employee theft base rate; however, the results produced a wide range from $3 \%$ to $62 \%$. These wide range rates were also obtained from sensitive self-report information; therefore, the results may remain inaccurate.

There are several additional reasons that cause employee theft to be underreported. One reason is that only detected theft can be reported, and most theft is detected by indirect means (not actually witnessing the act); therefore, businesses require a system of checks and balances where they can truly estimate the extent to which employee theft really affects them (Appelbaum et al., 2006). The concept of concealment by employees, in some cases, makes it more difficult for businesses to detect theft incidents. The extent to which employee theft affects a firm can be difficult to estimate because only a small proportion of employee theft is detected when it occurs (Bamfield, 2006). Unfortunately, the literature indicated that the majority of employee theft is not discovered. The data suggested that only very few employees are ever caught stealing, and it is estimated that as much as $80 \%$ of employee theft goes undetected (Oliphant \& Oliphant, 2001). Additionally, there are more factors contributing to inventory loss that businesses need to consider. For example, calculating inventory loss in the retail industry can be difficult because such losses occur for various reasons such as shoplifting, employee theft, vendor fraud, and administrative error (Bailey, 2006; Chapman \& Templar, 2006; Moorthy et al., 2010). Because the actual breakdown of loss from theft is impossible to obtain, known losses are normally much smaller than the unknown losses (Bamfield, 2006). As a result, the estimated contribution of employee theft rate is based on perceptions and businesses' best-informed guesses (Bamfield, 2006).

A study on employee theft in UK retailing (Bamfield, 2006) revealed an interesting finding. The estimated total loss during 2002-2004 was $£ 44.67$ million, but apprehended offenders were only responsible for $4.4 \%$ of the estimated total. In addition, among the estimated losses, only $9.4 \%$ was considered known losses, leaving $90.6 \%$ as unknown. Bamfield concluded that, if $90.6 \%$ of the estimated losses were undiscovered, a large number of employees must be stealing. Based on this finding, unknown theft does not guarantee that theft does not exist, and this result indicates that businesses cannot ignore the severity of employee theft. Employee theft is also underreported because some employees lack the requisite organizational commitment to motivate them to report misconduct to their employers. As such, employees may be reluctant to report employee theft by their coworkers because they empathize more with their coworkers rather than the organization (Appelbaum et al., 2006). For example, in a study on employee theft in retail, respondents were classified into two groups: nontakers and takers (Bailey, 2006). Nontakers were those who did not steal from employers, and takers were those who engaged in stealing (Bailey, 2006). The results showed that, although nontakers were more likely than takers to report employee theft, some reluctance to report employee theft incidents remained (Bailey, 2006).

Most managers know that fraud and unethical behaviors occur in the workplace; however, $40 \%$ say they would not report it (Johnson \& Indvik, 2002). This finding is another reason that contributes to underreporting of employee theft. Prior to conducting research about employee theft at a drug store, Oliphant and Oliphant (2001) had to persuade and convince the store manager that theft was occurring; however, the store manager believed that theft was a result of shoplifting. In conducting the study, although employee theft was clearly identified, the store manager still refused to report the incidents to upper management because the manager was concerned that the thefts would reflect his quality as a leader. Another reason theft remains unreported is that losses from employee theft can be difficult for a business to accept and handle. Businesses often attribute losses to external theft because of their attitude toward the issue, and they are often in denial of the level of theft by their own employees (Chapman \& Templar, 2006). Theft of inventory is considered one of the most common types of employee fraud, and research has indicated that businesses suffer most fraud losses from employees rather than 
from customers (Moorthy et al., 2010). Many organizations, however, still equate inventory loss with shoplifting, even though shoplifting is only one form of loss, which may contribute to only $20 \%$ of all stock losses compared with 60\% that results from employee theft (Moorthy et al., 2010).

Many expressions are used to replace the term "employee theft," e.g., shrinkage, spoilage, shortage, unaccounted loss, defalcation (Appelbaum et al., 2006). Managers often use these expressions because they are in denial and want to avoid the image of criminal activity (Appelbaum et al., 2006). In addition, because an employee is often considered "part of the family," it can be difficult for business owners to accept that someone they know would steal from them (Peterson \& Zikmund, 2004). As a result, shock and disbelief are common reactions when employees or colleagues are charged with fraud. A typical response from businesses is, "I never thought he/she would do something like that" (Peterson \& Zikmund, 2004, p. 31). Business owners may have a difficult time responding to employee theft and dishonesty. In some cases, when they discover an employee engaging in this behavior, they often refuse to accept it and see it is as an isolated incident. Many businesses, therefore, accept that shrinkage or loss of goods is normal, and they experience this normality for various reasons (Johnson \& Indvik, 2002). With this attitude, employers expect employees to steal; thus, employees view this behavior as acceptable and justifiable, which creates an organizational atmosphere that condones the behavior (Oliphant \& Oliphant, 2001). Employees can rationalize and exploit business owners' attitudes; therefore, stealing becomes virtually risk-free (Appelbaum et al., 2006). Theft is also a learned response where employees develop informal rules or perceptions regarding what can be stolen based on the corporate culture (Gross-Schaefer et al., 2000). As a result, employees who want to act ethically will be pressured to conform to the less ethical environment and will be expected to join or become involved in unethical activities (Gross-Schaefer et al., 2000).

Dishonest employees are less likely to be minimally processed when caught committing theft, and these employees can simply find employment elsewhere (Fikes, 2009). Previous research revealed that businesses are often reluctant to report an employee theft incident to the appropriate authority. According to Taylor (2003), employee theft is one of the four least-reported crimes, along with credit card fraud, employee fraud, and customer theft. Taylor indicated that, among these four crimes, only one out of four credit card frauds, one of five employee fraud, and one of five customer thefts are reported. In sharp contrast, only one out of every 17 employee theft incidents is reported to the police. Another interesting research was also conducted on how U.S. businesses handle employee theft compared with other countries. An analysis of employee theft in retail stores in 16 European countries revealed that 53\% of theft cases were reported to the police compared with only 5.9\% reported in the United States (Appelbaum et al., 2006). This indicates that European businesses are less tolerant of this behavior than U.S. businesses (Appelbaum et al., 2006). Reporting employee thefts to the police can send a clear signal to other employees that such behavior is not tolerated; unfortunately, many organizations handle this issue informally (Mustaine \& Tewksbury, 2002). Often there are reasons businesses decide to handle the issue within the organization. Sometimes they fail to act because of a real or perceived poor relationship with the police (Appelbaum et al., 2006). Business victims of employee theft were shown to have less faith in law enforcement and police and, as a result, fail to use law enforcement agencies to respond to employee theft (Appelbaum et al., 2006). This, in turn, undermines the effectiveness of law enforcement agencies and police (Appelbaum et al., 2006). Another reason for failing to take legal action is the fear of bad publicity (Geesey \& Rocha, 2012; Mohsin, 2006).

Despite these findings, organizations must address the impact and consequences of unethical behavior. If employees witness deviant behaviors that go unpunished or that no consequences result for unethical behavior, the culture within the organization will change negatively (Everton et al., 2007). Experts have suggested businesses to take the hard-line approach when employee theft is discovered. Research indicated that, once an employee is caught stealing, a severe punishment or disciplinary action can deter other employees from doing the same (Appelbaum et al., 2006). Snyder et al. (1991) explained the importance of prosecution in order to reduce employee theft. To avoid the undercutting of all other prevention measures (e.g., internal controls, prescreening measures) in the organization, Snyder et al. suggested that managers must be willing to exercise this approach by prosecuting employees when theft is discovered. Failure to take such action sends mixed signals that can cause confusion and frustration among employees across the organization.

Krippel et al. (2008) conducted a study regarding how organizations respond when employee theft is detected. The most common response was to fire the employee; the second was to inform other employees about the punishment the employee received; whereas prosecution ranked third. The response used least was suing for or requiring restitution of the amount stolen. A report on UK retail crimes revealed that the police apprehended only $40 \%$ of the perpetrators of employee theft cases in retailers (Mishra \& Prasad, 2006). The primary reasons for the low rate were as follows: prosecution takes too much time; the low rate of success in court; managers do not 
want to prosecute elderly or juvenile culprits; the penalties were not felt to be a deterrent; lack of evidence; internal discipline was sufficient; private settlements; employees disappeared; and the process cost is high (Appelbaum et al., 2006; Mishra \& Prasad, 2006). Notably, among all the cases referred to law enforcement, $70 \%$ were prosecuted successfully, $73.5 \%$ of those prosecuted pleaded guilty or no contest, and only $0.3 \%$ of perpetrators were acquitted (Daigle et al., 2009).

When employees are caught engaging in theft, it is important to punish the employees equally, whether they are top management or lower-level employees (Wang \& Kleiner, 2005). If management steals and is not punished, employees will view this behavior as acceptable; thus, this issue will continue to be a problem in the workplace (Wang \& Kleiner, 2005). For example, Gross-Schaefer et al. (2000) presented a case in which the CEO of a candy company took home a massive quantity of candy bars each night. He was later confronted and resigned, but no legal action was taken. As a result, the organization's productivity decreased considerably. Conversely, in a case regarding MasterCard, the organization took a hard-line approach to preventing employee theft by imposing fines, terminating employment, and prosecuting offenders (Gross-Schaefer et al., 2000). As a result, MasterCard claimed great success with dramatic reduction in theft (Gross-Schaefer et al., 2000). Despite success within various organizations, researchers argued that this hard-line approach can also have a negative impact within the organization, which includes fear, confusion, and reduced productivity due to concerns related to doing something wrong (Appelbaum et al., 2006; Nilsen, 2010). This can create the perception of a negative corporate culture and reduced morale in the honest employees (Appelbaum et al., 2006; Nilsen, 2010). Organizations must therefore appropriately and effectively balance the hard-line approach.

\section{Method}

Survey data were collected to achieve the purpose of the study. The survey featured a section in which the participants could indicate their employment status (e.g., unemployed, current employment for more than one month, and current employment for less than one month). Spencer's (2010) employee theft questionnaire was used to measure the rate of employee theft for the different types of theft: misusing time during work hours (time theft), misusing or taking an employer's property (property theft), dishonestly appropriating or hiding funds/money (embezzlement), obtaining small items for personal use (pilferage), and taking/changing confidential information without authorization (data and trade secret theft). The rate of employee theft was measured using five-point Likert scale items. The respondents indicated their frequency of employee theft with 1 $=$ never, $2=$ seldom, $3=$ occasionally, $4=$ often, and $5=$ very often .

Each employee theft was measured based on whether a student had ever engaged in the activities listed. The data collection took place at a local community college in Pennsylvania in the United States. A systematic sampling method of professors and instructors was used in the data collection. The researcher asked the selected professors and instructors for permission to distribute a survey in their classrooms. Upon their approval, the survey was distributed to undergraduate college students in the classrooms. The data collection took place over a 10-day period. Valid survey responses from 92 students were used to analyze the data for this study.

\section{Results and Discussion}

A total of 139 surveys were distributed to undergraduate college students in 10 different classes. All the students returned their surveys, but only 92 of the surveys qualified for the study. The remaining 47 surveys were considered unusable because the questionnaires had not been completed, some students were unemployed at the time, or some students had been employed for less than one month. The author decided to exclude the responses from students who had been employed at the time for less than a month, based on the assumption that they might not have had an adequate employment record to indicate the frequency of employee theft behavior.

Based on the results of the survey responses from the students, the majority (92.1\%) admitted to committing time theft, whereas $33.7 \%$ had committed some form of property theft. Regarding the remaining types of theft, 5.6\% of students had embezzled, $26.7 \%$ had committed pilferage, and $14.4 \%$ had committed data and trade secret theft, respectively.

Table 1. Percentage of College Students Who Committed Each Type of Theft

\begin{tabular}{ll}
\hline Type of Theft & \% \\
\hline Time theft & 92.1 \\
Property theft & 33.7 \\
Embezzlement & 5.6 \\
Pilferage & 26.7 \\
Data and trade secret theft & 14.4 \\
\hline
\end{tabular}


The findings discussed above were consistent with the previous research literature. Graves (2008) mentioned that college student employees' propensity toward theft in the workplace is on the rise. Harding, Carpenter, Finelli, and Passow (2004) also indicated that, among college student employees alone, approximately $48.8 \%$ have been tempted to engage in employee theft at least once. Based on these research findings and other research literature, employee theft among college students is clearly significant and deserves attention from the business community, so that appropriate steps can be taken to minimize the incidence of such theft and its consequences.

\subsection{Time Theft}

Time theft was by far the greatest form of theft committed by the students in this study, i.e., $92.1 \%$ of students whose questionnaires were accepted admitted to time theft. Some examples of time theft, often referred to as work withdrawal behaviors, include absenteeism, tardiness, low job involvement, leaving work early, doing personal matters during work hours, and taking unauthorized breaks (Henle, Reeve, \& Pitts, 2010; Kulas et al., 2007). When college student employees take such actions, they are stealing time. Moreover, time theft behaviors reduce productivity at work.

\subsection{Property Theft, Embezzlement, and Pilferage}

The second most common type of theft the college students committed was theft of property (33.7\%). Property theft is considered a major problem for retailers who experience shrinking inventories from the loss of merchandise as a result of employee and customer theft. However, employee theft alone contributes $47 \%$ or $\$ 15.8$ billion of shrinkage in the retail sector in the United States (Alstete, 2006). Property theft is similar to embezzlement and pilferage; however, the differences are based on the magnitude and authority of an individual who commits employee theft. The distinction between property theft and embezzlement is that embezzlement is committed by a person in authority. Albanese (2008) and Vanasco (1998) refer to embezzlement as intentional conversion or misappropriation of property entrusted to one's care. The distinction between property theft and pilferage is in the substance of the items stolen. In simple terms, pilferage refers to the stealing of small items or merchandise in small quantities for personal use (Russell, 2000; Vanasco, 1998). Pilferage of office supplies is common in many organizations, and it is a serious problem for U.S. businesses. As Wells (1994) indicated in his research, pilferage of office supplies amounts to approximately $\$ 1$ billion a year.

\subsection{Data and Trade Secret Theft}

With the advancement of technology, employee theft now is not only limited to tangible assets. Advances in technology enable employees to steal information such as trade secrets, customers' information, and other intellectual property. Although only $14.4 \%$ of college students admitted committing data and trade secret theft, for businesses to survive in a competitive economy, protecting their data and confidential information is critical (Camardella, 2004). For instance, in industries such as pharmaceuticals or biotechnology, the nature of the industry relies on new research and development, innovation, and protecting intellectual property. Camardella (2004) indicated that the theft of trade secrets and other intellectual property exceeds $\$ 250$ billion a year, and $75 \%$ of those who commit such theft are considered trusted insiders, including employees.

\section{Recommendations}

The findings from this study indicate and confirm that employee theft among college student workers is a significant issue. With the high amount of losses annually as a result of employee theft, this issue has important implications for businesses (Kulas et al., 2007). There is need for businesses to strive to understand the root behavioral causes to proactively manage the risks (Ramamoorti, 2008). College students are now considered an important element of the workforce because the majority of them are employed (Riggert et al., 2006). Therefore, the findings from this study offer new practical implications for businesses to consider.

Future research addressing the rate of employee theft among college students should expand further to include a more qualitative component that offers more in-depth information pertaining to this issue. Further, future research conducted at different educational settings such as the university or private university would provide additional information on this issue for this particular demographic. A larger sample size with more variety of participants from different educational disciplines would offer a broader perspective regarding the investigation of this issue as well. Additionally, expanding the research to focus on employees with different demographics is recommended, as Peterson and Zikmund (2004) indicated that previous research has failed to investigate the unique demographics of employees who engage in unethical behavior in the workplace. The investigation of more factors and other variables that have an impact on the rate of employee theft among college students would also be beneficial, as many unknown contributing variables still have an impact on this behavior (Gross-Schaefer et al., 2000). Additional findings of factors would definitely contribute to literature and be useful for business communities. Finally, it is 
recommended that the future research should be more industry- or organizational-setting specific, so the findings can be generalized within that particular industry or organizational setting.

\section{Conclusion}

This study's findings indicate that the prevalence of employee theft among college students is significant and is growing. With the magnitude of financial losses annually as a result of theft, this issue has important implications for businesses. Based on the survey results, time theft, property theft, and pilferage appear to be the most common types of theft committed by college students. The different types of theft discussed in this research and the findings of this study should help businesses and practitioners become aware of the issue of employee theft among college students. Employers, therefore, can proactively address this issue in a timely manner to prevent or minimize the cost of such behavior.

\section{References}

Aker, J. M. (2009). How to prevent office theft. IREM Insight, 31(4), 1-3. Retrieved from http://www.iremhou.com/

Albanese, J. S. (2008). White collar crimes and casino gambling: Looking for empirical links to forgery, embezzlement, and fraud. Crime, Law and Social Change, 49(5), 333-347. https://doi.org/10.1007/s10611-008-9113-9

Alstete, J. (2006). Inside advice on educating managers for preventing employee theft. International Journal of Retail and Distribution Management, 34(11), 833-844. https://doi.org/10.1108/09590550610710237

Appelbaum, S. H., Cottin, J., Paré, R., \& Shapiro, B. T. (2006). Employee theft: From behavioural causation and prevention to managerial detection and remedies. Journal of American Academy of Business, Cambridge, 9(2), 175-182. Retrieved from http://www.jaabc.com/

Bailey, A. A., (2006). Retail employee theft: A theory of planned behavior perspective. International Journal of Retail and Distribution Management, 34(11), 802-816. https://doi.org/10.1108/09590550610710219

Bamfield, J. (2006). Sed quis custodiet? Employee theft in UK retailing. International Journal of Retail and Distribution Management, 34(11), 845-859. https://doi.org/10.1108/09590550610710246

Bozick, R. (2007). Making it through the first year of college: The role of students' economic resources, employment, and living arrangements. Sociology of Education, 80(3), 261-284. https://doi.org/10.1177/003804070708000304

Buckhoff, T., Higgins, L., \& Sinclair, D. (2010). A fraud audit: Do you need one? Journal of Applied Business Research, 26(5), 29-33. https://doi.org/10.19030/jabr.v26i5.316

Camardella, M. (2004). Restrictive covenants. Employment Relations Today, 31(1), 110-115. https://doi.org/10.1002/ert.20011

Chapman, P., \& Templar, S. (2006). Scoping the contextual issues that influence shrinkage measurement. International Journal of Retail and Distribution Management, 34(11), 860-872. https://doi.org/10.1108/09590550610710255

Daigle, R., Morris, P., \& Hayes, D. (2009). Small businesses: Know thy enemy and their methods. The CPA Journal, 79(10), 30-37. Retrieved from http://www.cpajournal.com/

DeSimone, J. S. (2008). The impact of employment during school on college student academic performance. https://doi.org/10.3386/w14006

Everton, W. J., Jolton, J. A., \& Mastrangelo, P. M. (2007). Be nice and fair or else: Understanding reasons for employees' deviant behaviors. The Journal of Management Development, 26(2), 117-131. https://doi.org/10.1108/02621710710726035

Fikes, E. M. (2009). Dishonest associates in the workplace: The correlation between motivation and opportunity in retail among employee theft. Retrieved from http://dspace.uta.edu/bitstream/handle/10106/1650/Fikes_uta_2502M_10196.pdf?sequence=1

Fletcher, L., \& Miles, M. (1997). Small business and fraud: An exploratory study of small manufactures. Journal of Business and Entrepreneurship, 9(2), 61-70. Retrieved from http://www.jsbe.com/

Geesey, J., \& Rocha, C. (2012). Self control theory: Recognizing your companys vulnerability to employee theft. Journal of American Academy of Business, Cambridge, 17(2), 198-203. Retrieved from http://www.jaabc.com/journal.htm

Grannis, K. (2007). Retail losses hit $\$ 41.6$ billion last year, according to national retail security survey. 
Retrieved from National Retail Federation website:

http://www.nrf.com/modules.php?name=News\&op=viewlive \&sp_id=318

Graves, S. M. (2008). Student cheating habits: A predictor of workplace deviance. Journal of Diversity Management, 3(1), 15-22. https://doi.org/10.19030/jdm.v3i1.4977

Gross-Schaefer, A., Trigilio, J., Negus, J., \& Ceng-Si Ro. (2000). Ethics education in the workplace: An effective tool to combat employee theft. Journal of Business Ethics, 26(2), 89-100.

https://doi.org/10.1023/A:1006038310865

Henle, C. A., Reeve, C. L., \& Pitts, V. E. (2010). Stealing time at work: Attitudes, social pressure, and perceived control as predictors of time theft. Journal of Business Ethics, 94(1), 53-67. https://doi.org/10.1007/s10551-009-0249-z

Holtfreter, K. (2004). Fraud in U.S. organisations: An examination of control mechanisms. Journal of Financial Crime, 12(1), 88-95. https://doi.org/10.1108/13590790510625070

Jackson, K., Holland, D., Albrecht, C., \& Woolstenhulme, D. (2010). Fraud isn't just for big business: Understanding the drivers, consequences, and prevention of fraud in small business. Journal of International Management Studies, 5(1), 160-164. Retrieved from http://www.jimsjournal.org/

Johnson, P. R., \& Indvik, J. (2002). Too many hands in the cookie jar: Conflict between employees and organizations over theft. Proceedings of the Academy of Organizational Culture, Communications and Conflict, 7(2), 9-13. Retrieved from http://www.alliedacademies.org/Public/Journals/Journals.aspx

Kelly, P., \& Hartley, C. A. (2010). Casino gambling and workplace fraud: A cautionary tale for managers. Management Research Review, 33(3), 224-239. https://doi.org/10.1108/01409171011030381

Kidwell, R. E., \& Kochanowski, S. M. (2005). The morality of employee theft: Teaching about ethics and deviant behavior in the workplace. Journal of Management Education, 29(1), 135-152. https://doi.org/10.1177/1052562903261180

Krippel, G., Henderson, L., Keene, M., Levi, M., \& Converse, K. (2008). Employee theft and the coastal South Carolina hospitality industry: Incidence, detection, and response (Survey results 2000, 2005). Tourism and Hospitality Research, 8(3), 226-238. https://doi.org/10.1057/thr.2008.22

Kulas, J. T., McInnerney, J. E., Rachel, F. D., \& Jadwinski, V. (2007). Employee satisfaction and theft: Testing climate perceptions as a mediator. The Journal of Psychology, 141(4), 389-402. https://doi.org/10.3200/JRLP.141.4.389-402

Kulm, T. L., \& Cramer, S. (2006). The relationship of student employment to student role, family relationships, social interactions and persistence. College Student Journal, 40(4), 927-938. Retrieved from www.eric.ed.gov/ERICWebPortal/recordDetail?accno=EJ765393

Latto, A. (2007). Managing risk from within: Monitoring employees the right way. Risk Management, 54(4), 30-34. Retrieved from http://www.rmmag.com/

Lord, A. T. (2010). The prevalence of fraud: What should we, as academics, be doing to address the problem? International Journal of Accounting and Information Management, 9(1), 4-21. Retrieved from http://www.emeraldinsight.com

McClurg, L. A., \& Butler, D. S. (2006). Workplace theft: A proposed model and research agenda. Southern Business Review, 31(2), 25-34. Retrieved from http://coba.georgiasouthern.edu/centers/pub/Southern\%20Business\%20Review/chooseanissue.htm

Mishra, K. B., \& Prasad, A. (2006). Minimizing retail shrinkage due to employee theft. International Journal of Retail and Distribution Management, 34(11), 817-832. https://doi.org/10.1108/09590550610710228

Mohsin, A. (2006). A case of control practice in restaurants and cafes in Hamilton, New Zealand. Journal of American Academy of Business, Cambridge, 8(1), 271-276. Retrieved from http://www.jaabc.com/

Moorthy, M., Seetharaman, A., Arokiasamy, L., \& Marimuthu, M. (2010). Battling workplace theft. Interdisciplinary Journal of Contemporary Research in Business, 2(6), 337-357. Retrieved from http://ijcrb.webs.com/

Mustaine, E. E., \& Tewksbury, R. (2002). Workplace theft: An analysis of student-employee offenders and job attributes. American Journal of Criminal Justice, 27(1), 111-127. https://doi.org/10.1007/BF02898973

Niehoff, B. P, \& Paul, R. J. (2000). Causes of employee theft and strategies that HR managers can use for prevention. Human Resource Management, 39(1), 51-64. doi:10.1002/(SICI)1099-050X(200021)

Nilsen, K. (2010). Keeping fraud in the cross hairs. Journal of Accountancy, 209(6), 20-24. Retrieved from 
http://www.journalofaccountancy.com

Oliphant, B., \& Oliphant, G. (2001). Using a behavior-based method to identify and reduce employee theft. International Journal of Retail and Distribution Management, 29(10), 442-451. https://doi.org/10.1108/09590550110405321

Oliver, D. (2009). University student employment and experiences of union membership. Labour and Industry, 19(3), 137-156. https://doi.org/10.1080/10301763.2009.10669387

Omar, F., Halim, F. W., Zainah, A. Z., Farhadi, H., Nasir, R., \& Khairudin, R. (2011). Stress and job satisfaction as antecedents of workplace deviant behavior. World Applied Sciences Journal, 12, 46-51. Retrieved from http://idosi.org/wasj/wasj.htm

Peltier-Rivest, D. (2009). An analysis of the victims of occupational fraud: A Canadian perspective. Journal of Financial Crime, 16(1), 60-66. https://doi.org/10.1108/13590790910924966

Peterson, B. K., \& Zikmund, P. E. (2004). 10 truths you need to know about fraud. Strategic Finance, 85(11), 28-34. Retrieved from http://www.imanet.org/

Ramamoorti, S. (2008). The psychology and sociology of fraud: Integrating the behavioral sciences component into fraud and forensic accounting curricula. Issues in Accounting Education, 23(4), 521-533. https://doi.org/10.2308/iace.2008.23.4.521

Riggert, S. C., Boyle, M., Petrosko, J. M., Ash, D., \& Rudes-Parkins, C. (2006). Student employment and higher education: Empiricism and contradiction. Review of Educational Research, 76(1), 63-92. https://doi.org/10.3102/00346543076001063

Russell, S. H. (2000). Logistics crime-Knowing and managing the risks. Air Force Journal of Logistics, 24(1), 18-24. Retrieved from http://www.aflma.hq.af.mil/lgj/journals.asp

Sauser, W. (2007). Employee theft: Who, how, why, and what can be done. S.A.M. Advanced Management Journal, 72(3), 13-25. Retrieved from http://www.emeraldinsight.com

Snyder, N. H., Broome, O. W., Kehoe, W. J., McIntyre, J. T., \& Blair, K. E. (1991), Reducing Employee Theft. New York, NY: Quorum Books.

Spencer, L. (2010). A correlation analysis between employee theft and employee ownership (Doctoral dissertation). Retrieved from ProQuest Dissertations and Theses database (3415964).

Taylor, N. (2003). Under-reporting of crime against small businesses: Attitudes toward police and reporting practices. Policing and Society, 13(1), 79-89. https://doi.org/10.1080/1043946032000050562

Tootle, N. (2008). Six tips for avoiding fraud. Corporate Finance Review, 13(2), 26-31. Retrieved from $\mathrm{http}: / /$ ria.thomsonreuters.com/EStore/detail.aspx?ID=CMJP

Van Fleet, D. D., \& Van Fleet, E. W. (2006). Internal terrorists: The terrorists inside organizations. (2006). Journal of Managerial Psychology, 21(8), 763-774. https://doi.org/10.1108/02683940610713280

Vanasco, R. R. (1998). Fraud auditing. Managerial Auditing Journal, 13(1), 4-71. https://doi.org/10.1108/02686909810198724

Wang, Y., \& Kleiner, B. H. (2005). Defining employee dishonesty. Management Research Review, 28(2/3), 11-22. https://doi.org/10.1108/01409170510785057

Weber, J., Kurke, L. B, \& Pentico, D. W. (2003). Why do employees steal? Business and Society, 42(3), 359-380. https://doi.org/10.1177/0007650303257301

Wells, J. (1994). The billion dollar paper clip. Internal Auditor, 51(5), 32-33. Retrieved from https://iaonline.theiia.org/

Wells, J. T. (2003). Protect small business. Journal of Accountancy, 195(3), 26-32. Retrieved from http://www.journalofaccountancy.com/

Zeune, G. D. (2000). Are you teaching your employees to steal? Strategic Finance, 82(2), 34-39. Retrieved from http://www.imanet.org/

\section{Copyrights}

Copyright for this article is retained by the author(s), with first publication rights granted to the journal.

This is an open-access article distributed under the terms and conditions of the Creative Commons Attribution license (http://creativecommons.org/licenses/by/4.0/). 